\title{
Kepercayaan dan Pertentangan Ideologi dalam Cerpen "Cerita Lama Negara Suka dan Negara Neka" Karya Jelsyah Dauleng (Kajian Hegemoni Gramsci)
}

\author{
Fajrul Falah \\ Fakultas Ilmu Budaya, Universitas Diponegoro \\ fajrul.falah@live.undip.ac.id
}

\begin{abstract}
This study aims to revealed the beliefs and ideological contradictions in the short story "Cerita Lama Negara Suka dan Negara Neka” creation Jelsyah Dauleng. This research is based on fictional thoughts and ideas (short story) is a reflection of the writer's thoughts to the world of reality of the people being referred. Language and symbols in the short story, meaningful that needs to be expressed. The object of this research material is short story "Cerita Lama Negara Suka dan Negara Neka" published by Harian Haluan, 10 February 2019. This study uses a sociological approach, to reveal issue and social aspects contained in the short story, specifically enter the realm of Gramsci's hegemony. The research method used is descriptive qualitative. Research data obtained from the short story text (words, phrases, sentences) that are relevant to Gramsci's ideology, beliefs, social aspects and hegemony. The research data is then interpreted according to the approach used, then presented descriptively. The results of the research on this short story showed that there was a conflict between group members then each group separated and created their respective countries. Conflict and the separation of the two countries Successfully muted because of group members Negara Neka trust belief Negara Suka, namely a life full of peace, kindness, and other realms. Trust Negara Neka to Negara Suka finally fade after a disaster. Group Negara Neka returned to the ideology it believed.
\end{abstract}

Keywords: Ideology; trust, state, hegemony, and sociology.

\section{Intisari}

Penelitian ini memiliki tujuan mengungkapkan kepercayaan dan pertentangan ideologi dalam cerpen "Cerita Lama Negara Suka dan Negara Neka" Karya Jelsyah Dauleng. Penelitian ini didasari oleh pemikiran dan gagasan bahwa fiksi (cerpen) merupakan refleksi pemikiran pengarang terhadap dunia realitas masyarakat yang diacu. Bahasa dan simbol dalam cerpen tersebut, penuh makna yang perlu diungkapkan. Objek material penelitian ini cerpen "Cerita Lama Negara Suka dan Negara Neka" yang diterbitkan oleh Harian Haluan, 10 Februari 2019. Penelitian ini menggunakan pendekatan sosiologi sastra, untuk mengungkapkan persoalan dan aspek sosial yang terdapatat dalam cerpen, yang secara spesifik masuk ranah hegemoni Gramsci. Metode penelitian yang dipakai adalah deskriptif kualitatif. Data 
penelitian didapatkan dari teks cerpen tersebut (kata, frasa, kalimat) yang relevan dengan ideologi, kepercayaan, aspek sosial dan hegemoni Gramsci. Data penelitian kemudian diinterpretasikan berdasarkan pendekatan yang dipakai, lalu disajikan secara deskriptif. Hasil penelitian terhadap cerpen tersebut menunjukkan terjadi konflik antaranggota kelompok yang kemudian tiap-tiap kelompok itu berpisah dan membuat negara masing-masing. Konflik dan terpisahnya dua negara tersebut berhasil diredam sesaat karena anggota kelompok Negara Neka mempercayai keyakinan Negara Suka, yakni hidup penuh kedamaian, kebaikan, dan alam lain. Kepercayaan Negara Neka terhadap Negara Suka akhirnya memudar setelah terjadi bencana, Kelompok Negara Neka kembali kepada ideologi yang dipercayainya.

Kata kunci: Ideologi; kepercayaan; negara; hegemoni; dan sosiologi.

\section{Pendahuluan}

Kepercayaan suatu individu atau sebagian masyarakat bisa dikategorikan dalam tiga tahapan. Pertama, individu sekadar mempercayai terhadap paham atau pandangan-pandangan tertentu tanpa aktif melakukan tindakan. Kedua, individu mempercayai dan mengimplementasikan dalam kehidupan sehari-hari. Ketiga, individu juga aktif mendistribusikan kepercayaan tersebut dan berupaya mempengaruhi individu lain. Kepercayaan dan ideologi (pandangan) tidak datang dengan sendiri, melainkan membutuhkan proses dan memerlukan keterlibatan banyak pihak. Ada motif dan kepentingan yang terus menerus diperjuangan untuk merebutkan suara massa atau pengikut. Ketika kepercayaan dan ideologi itu didistribusikan, muncul pihakpihak baik yang pro (setuju), maupun kontra (menolak).

Konflik antarpihak dan kepercayaan itu diindikasikan termuat dalam cerpen "Cerita Lama Negara Suka dan Negara Neka" Karya Jelsyah Dauleng (selanjutnya disingkat CLNSdN). Cerpen ini diterbitkan Harian Haluan pada 10 Februari 2019. Objek cerpen ini diambil pada laman https://lakonhidup.com/2019/02/10/cerita-lama-negara-suka-dan-negaraneka/. Mengapa dalam cerpen muncul kepercayaan-kepercayaan dan ideologi tertentu. Tiaptiap tokoh dalam cerpen tersebut pun mengapa yakin dengan kepercayaan masing-masing. Bagaimana pula tiap-tiap kepercayaan tumbuh dijalankan sehingga memilki pengikut. Bagaimana pula reaksi pihak-pihak yang tidak sepaham dengan ideologi yang tidak dipercayainya. Latar dalam cerpen tersebut memakai nama Negara Neka dan Negara Suka. Latar yang diindikasikan memiliki makna dan terkait dengan dunia realitas yang diacu oleh pengarang. Demikian halnya dengan pandangan dari tiap-tiap tokoh fiksi dalam masing- 
masing kelompok terkait surga dan neraka. Persoalan dan pertanyaan-pertanyaan tersebut menarik ditujukan pada cerpen tersebut.

Penelitian ini bertujuan (1) mendeskripsikan sinopsis cerpen "Cerita Lama Negara Suka dan Negara Neka", dan (2) mengungkapkan kepercayaan dan ideologi yang terdapat dalam cerpen "Cerita Lama Negara Suka dan Negara Neka" karya Jelsyah itu. Tujuan tersebut bisa diungkapkan dengan pendekatan hegemoni Gramsci. Berdasarkan penelusuran yang telah penulis lakukan, melalui jelajah internet atau google dengan memasukkan kata kunci "Cerpen "Cerita Lama Negara Suka dan Negara Neka", dan jurnal online yang terindeks doaj.org., belum ditemukan penelitian terhadap cerpen tersebut. Meskipun demikian, penelitian terkait kepercayaan, ideologi, dan hegemoni penulis temukan di jurnal-jurnal online. Beberapa penelitian yang terkait dengan penelitian ini sebagai berikut.

Penelitian terkait ideologi dan hegemoni dilakukan oleh (1) Falah (2019) terhadap cerpen "Surga untuk Lelaki yang Tertipu" Karya Adam Yudhistira. Tujuan dan fokus penelitian ini mengungkapkan ideologi dan hegemoni tokoh dalam cerpen tersebut. Hasil analisis menunjukkan tokoh guru dan murid (Santo) memiliki relasi patron-klien. Relasi itu menguntungkan tokoh guru untuk mengendalikan Santo (Falah, 2019a). Penelitian lain dilakukan juga oleh (2) Falah mengkaji kepercayaan dan hegemoni dalam Cerpen "Makelar" Karya Sri Lima R.N. Fokus dan tujuan penelitian ini mengungkapkan kepercayaan dan hegemoni dalam cerpen tersebut dengan pendekatan hegemoni Gramsci. Hasil penelitian menunjukkan tokoh Handoko menjadikan profesinya sebagai makelar untuk menghegemoni masyarakat dan mendapatkan keuntungan (Falah, 2019b).

(3) Baihaqi mengkaji ayat-ayat legitimatif Al-Quran pada Kasus Suksesi Abu Bakr Al Siddiq dengan objek formal ideologi politik dalam khazanah penafsiran. Fokus penelitian ini mendiskusikan polemik politik Islam dan berbagai jenis interpretasi Al Qurna yang mengakibatkan perselisihan teologis dan memunculkan tiga aliran, yakni Sunni, Syi'ah, dan Mu'tazilah. Hasil penelitian menunjukkan penerjemah Al-Quran dipengaruhi sejarah, keahlian, dan idelogi politik yang dianutnya (Baihaqi, 2019). Penelitian terkait ideologi dilakukan oleh (4) Falah, mengkaji novel Matinya Sang Penguasa karangan El Saadawi. Fokus penelitian ini pada kajian sastra Marxis. Hasil Penelitian menunjukkan ideologi 
pengarang nampak berpihak pada tokoh-tokoh perempuan yang memperjuangkan hak-haknya (kesetaraan)(Falah, 2017). Penelitian terkait hegemoni ideologi dilakukan (5) Falah dengan objek material novel Ayat-Ayat Cinta karangan Habiburrahman el Shirazy. Penelitian ini berlandaskan pemikiran bahwa novel bukan sekadar menyampaikan cerita dan memakai bahasa indah (estetik), melainkan juga ada motif dan pesan pengarang. Hasil penelitian menunjukkan relasi antar tokoh berjalan baik karena menjalankan dan terhegemoni nilai-nilai agama Islam (Falah, 2018).

Penelitian-penelitian yang telah disebutkan itu, menggunakan objek material yang berbeda dengan penelitian ini. Penulis mengkaji cerpen "Cerita Lama Negara Sukda dan Neka" untuk mengungkapkan kepercayaan dan ideologi dalam cerpen tersebut. Cerpen itu sekalipun secara space (empat halaman, A4 dan 1.092 kata) dan narasi relatif terbatas, namun memuat pesan-pesan yang padat yang sarat muatan ideologis yang penting untuk diungkapkan melalui pendekatan hegemoni Gramsci. Hegemoni bisa dimaknai sebagai bentuk kekuasaan melalui kepemimpinan dengan cara-cara halus, yakni persetujuan (konsensus), bukan melalui paksaan apalagi mekmakai cara-cara kekerasan atau militeristik (Lihat juga Gramsci, 1971:57; Simon, 2001:21; Falah, 2018). Konsep kekuasaan hegemoni dijalankan diantaranya melalui penyebaran ideologi. Ideologi tumbuh melalui kepercayaan-kepercayaan individu atau kelompok. Menurut Marx ideologi dalam karya sastra merupakan kesadaran, kepercayaan, keyakinan, dan gagasan yang dipercaya individu yang terkait dengan aktivitas material masyarakat (Lihat Kurniawan, 2012:44-46;Falah, 2017).

Kelompok dominan ingin menguasai kelompok subordinat melalui gagasan dan caracara ideologis (Althusser melalui Fiske, 1996:117-118). Ideologi memiliki peran mengikat kelas sosial lain yang antagonis atau kontra, menjadi bersatu dan harmonis. (Lihat Faruk 2010: 135-136; Kurniawan, 2012: 74). Tiap-tiap individu atau kelompok menganggap ideologinya yang paling benar. Dalam konteks beragama pun demikian, kebenaran agama itu benar menurut menurut pemeluknya atau umat (Lihat Thohir, 2018). Ideologi tumbuh melalui kepercayaan-kepercayaan individu atau kelompok. Kepercayaan merupakan modal/ikatan sosial. Kepercayaan mampu memberikan intervensi terhadap kelompok atau komunitas lain (Lihat Setyawati et al., 2010; Giddens, 2001). Kepercayaan dan ideologi dalam konteks cerpen "Cerita Lama Negara Suka dan Negara Neka", dimaknai sebagai keberterimaan kelas sosial 
tertentu terhadap gagasan-gagasan yang diyakini kebenarannya. Gagasan itu kemudian digunakan untuk mempegaruhi/intervensi kelompok atau kelas sosial lain supaya menajadi pengikutnya (sepaham).

\section{Metode Penelitian}

Penelitian ini menggunakan objek material cerpen berjudul "Cerita Lama Negara Suka dan Negara Neka" yang telah dimuat di Harian Haluan, 10 Februari 2019. Objek formal penelitian ini ialah kepercayaan dan pertentangan ideologi yang terdapat dalam cerpen tersebut. Pendekatan penelitian yang digunakan ialah sosiologi sastra, lebih khusus hegemoni Gramsci. Metode penelitian yang digunakan ialah deskriptif kualitatif. Penelitian ini masuk ranah penelitian kepustakaan. Langkah-langkah kerja yang digunakan dalam penelitian ini, yaitu pengumpulan data, analisis data, dan penyajian hasil analisis data. Langkah pengumpulan data dilakukan dengan cara menentukan objek, yakni cerpen "Cerita Lama Negara Suka dan Negara Neka". Kemudian cerpen dibaca secara detail dan menandai kata, frasa, kalimat, dan wacana dalam cerpen itu yang relevan dengan kepercayaan dan hegemoni. Data dari cerpen itu kemudian dianalisis dengan cara diinterpretasikan berdasarkan pendekatan hegemoni Gramsci. Hasil analisis disajikan atau dipaparkan secara deskriptif.

\section{Hasil dan Pembahasan}

Bab hasil dan diskusi memuat tiga subbab, yaitu sinopsis cerpen, kepercayaan Negara Neka dan Suka, dan ideologi keagamaan yang terdapat dalam cerpen "Cerita Lama Negara Suka dan Neka" karya Jelsyah Dauleng. Sinopsis dipaparkan untuk mengetahui gambaran cerpen dan memudahkan dan memfokuskan analisis.

\section{Sinopsis Cerpen CLNSdN}

Cerpen $C L N S d N$ sarat muatan ideologi keagamaan, sekalipun secara space relatif terbatas. Cerpen ini memuat diksi dan makna yang memiliki relevansi dengan keagamaan seperti ibadah, kewajiban, pahala, azab, bahkan surga dan neraka. Cerpen ini mengisahkan dua tokoh yang bersahabat, yakni Pak Neka dan Suka. Dua tokoh itu, sekalipun bersahabat, namun memiliki banyak perbedaan pandangan. Dua tokoh itu pun hidup dalam alam fiksi yang berbeda. Tiap-tiap tokoh dalam cerpen itu tidak hanya mempercayai keyakinannya masing- 
masing, melainkan juga mengajak tokoh lain untuk mengikuti keyakinannya. Hal itu nampak saat tokoh Pak Suka ingin mempengaruhi Pak Neka. Relasi dua tokoh itu pun naik turun, bisa harmonis dan dalam momen tertentu terlibat dalam perdebatan ideologi tokoh masing-masing. Perdebatan dua tokoh itu kembali meruncing saat pernyataan-pernyataan Pak Neka nampak angkuh terhadap Pak Suka. Pak Suka dalam hal ini posisinya terkuasai oleh Pak Neka.

Konsekuensi perbedaan ideologi yang semakin nampak, mengakibatkan tokoh Pak Neka dan Pak Suka konflik dan berpisah. Ada dua negara atau kelompok, yakni Negara Neka dan Negara Suka. Kelompok atau penduduk Negara Suka menyakini kepercayaan dan ideologi Pak Suka. Demikian pula penduduk Negara Neka yang menganut pendirian dan ideologi Pak Neka.

Penduduk Negara Suka memiliki keyakinan bahwa ada kehidupan lain setelah kehidupan di dunia (bumi). Orientasi aktivitas penduduk Negara Suka pun ditujukan tidak sekadar pada dunia, tetapi kehidupan setelahnya. Berbeda dengan penduduk Negara Neka yang tiap aktivitas pekerjaan yang dijalankan cenderung bebas tanpa batasan waktu.

Konflik belum berhenti sekalipun dua tokoh itu telah memiliki kelompok dan negara masing-masing. Kedua tokoh itu pun masih mempengaruhi satu sama lain. Pak Neka mengajak kepada Pak Suka untuk ikut dan masuk ke negaranya. Pak Suka pun memberikan nasihat kepada Pak Neka untuk tidak memberikan hak kebebasan dalam bertindak kepada anggotanya. Penduduk dua negara itu pun tidak saling terpengaruh, bahkan mencela satu sama lain. Setelah terjadi bencana di Negara Neka, penduduk negara itu kemudian tertarik dan bergabung ke Negara Suka. Penduduk Negara Neka merasa mendapatkan kebaikan, kebahagiaan, dan kedamaian di Negara Suka. Relasi baik antara mantan penduduk Negara Neka dan Suka hanya berjalan sesaat. Penduduk baru Negara Suka itu mengalami musibah di Negara Suka, sehingga dengan segera mereka meninggalkan dan kembali ke Negara Neka.

\section{Kepercayaan Negara Neka dan Suka}

Kepercayaan antara Negara Neka dan Suka memiliki perbedaan. Negara Neka mempercayai bahwa tindakan atau perilaku tiap-tiap individu berlandaskan kebebasan, bukan aturan-aturan yang mengikat. Kebebasan itu membuat mereka menikmati kehidupan tanpa ada kekhawatiran memikirkan akibat. Fokus tindakan atau kehidupan Negara Neka adalah dunia saat ini. Negara 
Neka yang dipimpin oleh Pak Neka itu hidup penuh dengan kecukupan, "Kita hanya hidup sekali. Kau juga tahu itu. Jadi biarlah kau juga menikmati apa yang kunikmati” (CLNSdN, 2019:2). Kutipan tersebut menunjukkan kepercayaan terhadap kebebasan menikmati hidup. Hidup dijalani bukan soal mendapatkan sanksi (punishment) dan apresiasi (reward), tetapi dinikmati (kebebasan). Kepercayaan terhadap kebebasan hidup Pak Neka inilah yang kemudian mendapatkan pertentangan dari Pak Suka.

Pak Suka merupakan pemimpin Negara Suka. Negara Suka mempercayai bahwa ada kehidupan lain setelah kehidupan di dunia ini. Fokus kehidupan Negara Suka bukan pada dunia saat ini, tetapi setelahnya. Dunia saat ini sebagai jembatan untuk menuju dunia masa depan (setelahnya). Konsekuensi logis dari fokus dan kepercayaan Negara Suka adalah menjalani kehidupan dengan mempertimbangkan aturan-aturan yang dipercayainya. Negara Suka mempercayai bahwa segala ucapan dan perbuatan yang dilakukan di dunia akan mendapatkan balasan kelak, "Akan ada masa di mana kita akan dimintai pertanggungjawaban atas semua tindakan yang kita lakukan di dunia ini” suara Pak Suka meninggi (CLNSdN, 2019:1). Kutipan tersebut menunjukkan kehidupan Pak Suka penuh dengan kehati-hatian, segala tindakan dipertimbangkan, tidak seperti Pak Neka dan negaranya yang cenderung bebas. Kehidupan Negara Suka secara ekonomi pun lebih sederhana dibandingkan Negara Neka. Hal itu dikarenakan dunia atau aspek ekonomi bukan menjadi fokus dan tujuan utama Negara Suka.

\section{Pertentangan Ideologi}

Pertentangan ideologi dalam cerpen CLNSdN direpresentasikan melalui tokoh Pak Neka dan Suka. Pak Neka mendirikan Negara Neka, demikian pula Pak Suka yang memiliki Negara Suka. Dua tokoh itu sebagai pemimpin masing-masing negara yang memiliki penduduk atau pengikut. Dua tokoh utama dalam cerpen tersebut sekalipun bersahabat, namun secara pandangan ideologi bertentangan. Pak Neka menganut ideologi kebebasan, sedangkan Pak Suka penuh dengan aturan dan keterikatan. Pertentangan ideologi dua tokoh itu buktikan melalui perdebatan atau adu argumentasi terkait pandangan tentang hidup. Pak Neka meremehkan bahkan cenderung menghina pandangan Pak Suka terkait hidup sebelum ada bukti nyata "Jangan bicara tentang hidup dengan kau yang tidak punya apa-apa" gumam Pak 
Neka (CLNSdN, 2019:2). Kutipan tersebut menunjukkan dominasi posisi Pak Neka terhadap Pak Suka. Ekonomi dijadikan alat oleh Pak Neka untuk menguatkan posisi dan argumentasinya sekaligus melemahkan Pak Suka.

Pak Neka menjadikan modal ekonomi sebagai alat untuk menguasai Pak Neka. Cara tersebut tidak membuat Pak Suka, tersinggung, marah, dan tunduk atau mengikuti Pak Neka. Hal itu karena Pak Suka menganut ideologi yang mempercayai ada kehidupan abadi (kekal) setelah kehidupan di dunia yang sementara ini (fana). Orientasi hidup Pak Suka bukan dunia saat ini, tetapi kehidupan abadi, sehingga kondisi ekonomi dirinya yang sederhana tidak menjadi masalah. Ideologi dalam konteks ini mampu meredam dan mengikat penganutnya dari godaan-godaan ideologi dari luar yang bertentangan. Ideologi tidak berjalan sendiri atau otomatis, ada pihak yang memproduksi (pencipta), mendistribusi (penyebar), dan mengkonsumsi (penganut). Hal demikian dibuktikan dalam cerpen CLNSdN saat Pak Neka mempengaruhi Pak Pak Suka untuk ikut negaranya, namun ditolak (CLNSdN, 2019: 3). Hal itu menunjukkan individu yang sudah menganut ideologi tertentu tidak mudah dipengaruhi oleh orang lain yang berbeda ideologi.

Ideologi yang menjadi instrumen penting dalam proses hegemoni (kekuasaan) dalam cerpen $C L N S d N$ pada awalnya berjalan baik. Pak Neka dan Pak Suka sekalipun bertentangan, namun konflik tidak sampai menimbulkan pembunuhan atau menghilangkan nyawa seseorang. Dua tokoh itu sebatas memperjuangkan ideloginya dan mepengaruhi satu sama lain. Hegemoni ideologi tidak berjalan baik (berhasil), manakala hanya sebatas argumentasi yang terus-menerus disuarakan tanpa ada bukti nyata. Hal itu dibuktikan saat penduduk Negara Neka yang awalnya hidup penuh kebebasan mengalami bencana dan berpindah mengikuti ke Negara Suka (Lihat CLNSdN, 2019: 4). Negara Suka merupakan negara di bawah pimpinan Pak Suka yang menawarkan hidup penuh kedamaian. Penduduk Negara Neka yang hanya tinggal sementara di Negara Suka. Penduduk Negara Neka yang awalnya mempercayai dan megharapkan kedamaian di Negara Suka, mulai hilang kepercayaan. Hal itu terjadi saat di Negara Suka juga terjadi bencana dan akhirnya penduduk Negara Neka pun meninggalkannya dan kembali pada negara asalanya (Neka). Dengan demikian maka, ideologi yang dianut sebagian individu dalam cerpen akan berhasil manakala bisa diwujudkan dalam kenyataan. 


\section{Simpulan}

Perbedaan kepercayaan dan ideologi antara Negara Neka dengan Negara Suka menimbulkan konflik. Konflik disebabkan oleh tiap-tiap negara saling mempengaruhi satu sama lain. Tiaptiap Negara mempercayai kebenaran sesuai dengan ideologinya masing-masing. Negara Neka menjalani hidup penuh kebebasan tanpa mempertimbangkan akibat, sedangkan Negara Suka menjalani hidup penuh dengan kehati-hatian (ada balasan). Negara Suka mempercayai ada kehidupan lain setelah kehidupan yang saat ini dijalaninya. Tiap-tiap negara memiliki anggota yang patuh sesuai dengan idelogi yang dianutnya. Hal itu menunjukkan pada awalnya ideologi mampu menyemen atau mengikat sekelompok individu untuk tetap patuh dan tidak melakukan perlawanan bahkan pemberontakan. Ideologi suatu kelompok yang sudah menguat bisa memudar atau melemah mankala tidak diproduksi (diciptakan), didistrubusi (disebarkan), dan dikonsumsi (dilaksanakan). Hal itu terjadi ketika anggota Negara Neka berpindah haluan mengikuti Negara Suka yang dilihatnya mampu menjalani hidup penuh kedamaian dan kesejahnteraan. Akan tetapi hal demikian hanya berlangsung sesaat, karena apa yang diharapkan Negara Neka (damai dan sejahtera) tidak bisa dibuktikan secara langsung di Negara Suka. Cerpen CLNSdN ini sarat muatan kepercayaan dan ideologi yang direpresentasikan oleh tokoh-tokoh fiksi masing-masing.

\section{Daftar Pustaka}

Baihaki, B. (2019). Ideologi Politik dalam Khazanah Penafsiran: Ayat-ayat Legitimatif alQur'ān pada Kasus Suksesi Abū Bakr al-Șiddīq. Islamika Inside: Jurnal Keislaman dan Humaniora, 5(1), 1-25. https://doi.org/10.35719/islamikainside.v5i1.40.

Dauleng, Jelsyah. 2019. “Cerita Lama Negara Suka dan Negara Neka”. Harian Haluan. Diakses melalui https://lakonhidup.com/2019/02/10/cerita-lama-negara-suka-dannegara-neka/. Pada 2 Juli 2019 pukul 20.07 WIB.

Falah, F. (2017) 'Ideologi Pengarang dalam Novel Matinya Sang Penguasa Karya Nawal el Sadawi: Kajian Sastra Marxis', 12(2), pp. 100-107.

Falah, F. (2018) 'Hegemoni Ideologi dalam Novel Ketika Cinta Bertasbih Karya Habiburrahman el Shirazy (Kajian Hegemoni Gramsci)', Nusa: Jurnal Ilmu Bahasa dan Sastra, 13(4), p. 533. doi: 10.14710/nusa.13.4.533-542.

Falah, F. (2019a) 'Hegemoni Ideologi dalam Cerpen "Surga untuk Lelaki yang Tertipu” Karya Adam Yudhistira (Kajian Hegemoni Gramsci)', Nusa: Jurnal Ilmu Bahasa dan Sastra, 14(1), p. 1. doi: 10.14710/nusa.14.1.1-10. 
Falah, F. (2019b) 'Kepercayaan dan Hegemoni dalam Cerpen "Makelar” Karya Sri Lima R.N. (Kajian Hegemoni Gramsci)', Nusa: Jurnal Ilmu Bahasa dan Sastra, 14(2), p. 136. doi: 10.14710/nusa.14.2.136-146.

Falah, F. (2018). "Ayat-ayat Cinta" , 13(3), pp. 351-360.

Faruk. 2010. Pengantar Sosiologi Sastra dari Strukturalisme Genetik sampai PostModernisme. Yogyakarta: Pustaka Pelajar.

Fiske, John. 1996. "British Cultural Studies and Television", dalam John Storey (ed). What is Cultural Studies?: A Reader. London: Arnold.

Giddens, A. 2011. The Consequences of Modernity. USA: Stanford University Press.

Kurniawan, Heru. 2012. Sosiologi Sastra: Teori, Metode, dan Aplikasi. Purwokerto: Graha Ilmu.

Setyawati, G. et al. (2010) 'Modal Sosial dan Pemilihan Dukun dalam Proses Persalinan: Apakah Relevan ? Jurnal Makara, Kesehatan, 14(1), pp. 11-16.

Thohir, M. (2018) 'Mendialogkan Kehidupan Keagamaan', Nusa: Jurnal Ilmu Bahasa dan Sastra, 13(3), p. 460. doi: 10.14710/nusa.13.3.460-470. 